\title{
DOSAGE DETERMINATION IN THE USE OF RADIOACTIVE ISOTOPES
}

\author{
BY LEONIDAS D. MARINELLI ${ }^{1}$ \\ (From the Physics Department, Memorial Hospital, New York City)
}

\section{INTRODUCTION}

As commonly used, most radioactive isotopes are ingested or injected in soluble form and subsequently deposited with a greater or lesser degree of selectivity in various cells and organs. In the event of a single administration, the number of radioactive atoms present at any particular site will increase at first (as they are drawn from the circulation along with their stable isotopes), it will reach a maximum and, as the source of supply becomes exhausted, it will decrease on account of both metabolic turnover and radioactive decay. The latter is accompanied by the release of ionizing radiation, the type and emission rate of which is the exclusive characteristic of the radioelement itself.

The direct measurement of radiation released in this manner in terms of units already established in Radiology is beset with numerous difficulties of experimental nature. Nevertheless when the physical factors of half life and radiation energy, and the physiological factors of uptake and excretion, are known, it is possible, in some cases at least, to make satisfactory estimates of tissue dosage.

The roentgen, as defined by international agreement, applies only to $\mathrm{x}$ - or gamma radiation; it can therefore be used for gamma ray emitting isotopes but not for radiation due to primary beta particles. (The roentgen is defined as "that quantity of $\mathrm{x}$ - or gamma radiation such that the associated corpuscular emission per $\mathbf{0 . 0 0 1 2 9 3}$ gram of air produces, in air, ions carrying one e.s.u. of quantity of electricity of either sign.")

On the other hand if the energy absorbed per gram of air per roentgen ( $\sim 83$ ergs) is made the unit of energy absorption for beta rays, it is possible to establish a comparable basis for beta ray dosage. To be sure, in going from air to tissues certain corrections will have to be made because the energy absorption in tissue per roentgen exposure of $\mathrm{x}$ - and gamma rays depends

1 On leave of absence to the Argonne National Laboratory, Chicago, Ill. on both tissue composition and radiation wavelength, but in practice, for soft tissues, these corrections are not very large. Hence it is possible to define an "equivalent roentgen" as "that amount of beta radiation which, under equilibrium conditions, releases in one gram of air as much energy as one roentgen of gamma rays." Since the accepted symbol for the roentgen is " $r$," it is convenient to designate the equivalent roentgen by "e.r." (This is essentially the same unit as the "rep" or "roentgen equivalent physical" of the Plutonium Project.) In the present paper, formulae expressing the relationship between radiation dose and isotope concentrations are presented and their clinical applications discussed by the use of tables containing a considerable amount of pertinent information. Examples of application of the formulae to specific isotopes and definite problems will also be given. For the mathematical and physical aspects of the problem the reader is referred to the literature $(1,2)$.

\section{CALCULATIONS}

Beta Ray Emitters. When a radioisotope emits only beta rays, the dose is essentially confined to the regions containing the material because the range of the beta particles in tissue is only a few mm. Many organs in small animals used in experiments dealing with isotopes emitting high-energy beta rays are not small in comparison to the range of the beta particles. Proper estimate of the dose in these instances is, in general, very complicated, and must be left to the future.2

The total dose $D_{\beta}$, in equivalent roentgens, due to the complete disintegration of a radioelement biologically stable and present in a uniform concentration of $\mathrm{C}$ microcuries per gram of tissue is

where

$$
\mathrm{D}_{\beta}=\mathrm{K}_{\beta} \mathrm{C} \text { e.r. }
$$

$$
\mathrm{K}_{\beta}=88 \overline{\mathrm{E}}_{\beta} \mathrm{T} \text { e.r. per } \mu \mathrm{cd} .^{3} \text { per gram; }
$$

$\mathrm{T}$ is the half life of the isotope in days and $\overline{\mathrm{E}}_{\beta}$ the average energy per disintegration of the beta rays in million electron volts (Mev).

2 This problem is somewhat similar to the problem of gamma emitters (vide infra).

${ }^{3} \mu \mathrm{cd}$.-microcuries destroyed, i.e., microcuries completely disintegrated in the tissue. 
Doses per hour and per day are respectively

$$
\left.\begin{array}{l}
d_{\beta} \text { (hour) }=D_{\beta} f_{h} \\
d_{\beta} \text { (day) }=D_{\beta} f_{d}
\end{array}\right\}
$$

where $f_{d}$ and $f_{h}$ are the fractions of the entire quantity of the isotope which disintegrate per hour or per day respectively. Values of $T, \bar{E}_{\beta}, K_{\beta}$ and $f_{d}$ are given in Table I which refers to beta ray emitters. $Z$ is the atomic number and $\mathrm{A}$ the atomic weight of the elements given in the first

TABLE I

\begin{tabular}{|c|c|c|c|c|c|c|c|c|c|c|}
\hline Element & $Z$ & $\mathbf{A}$ & Radiation & $\begin{array}{c}\text { T } \\
\text { Half life } \\
\text { in days }\end{array}$ & $\underset{\left(\mathbf{M} e_{\beta}\right)}{\overline{\mathbf{E}}_{\beta}}$ & $\underset{\substack{\mathbf{K}_{\beta} \\
\text { per. } \\
\text { gram }}}{ }$ & $\begin{array}{c}\mathbf{f}_{d} \\
\text { fraction } \\
\text { disintegr. } \\
\text { per day }\end{array}$ & $\stackrel{\mathrm{S}_{\beta}}{\mu c \text { per } k g}$ & $\begin{array}{l}\text { Weight } \\
\text { per mc in } \\
10^{-9} \text { gram }\end{array}$ & $\begin{array}{c}\text { Maximum } \\
\text { range in } \\
\text { water } \\
(\mathrm{mm})\end{array}$ \\
\hline
\end{tabular}

Physical data pertaining to calculations of radiation dosage resulting from beta rays and/or very soft $x$-ray radiation

\begin{tabular}{|c|c|c|c|c|c|c|c|c|c|c|}
\hline $\begin{array}{l}\mathrm{Na} \\
\mathrm{P} \\
\mathrm{K} \\
\mathrm{Sc} \\
\mathrm{V} \\
\mathrm{Mn} \\
\mathrm{Fe} \\
\mathrm{Co} \\
\mathrm{Cu} \\
\mathrm{As} \\
\mathrm{Br} \\
\text { In } \\
\mathrm{I} \\
\mathrm{RaE}\end{array}$ & $\begin{array}{l}11 \\
15 \\
19 \\
21 \\
23 \\
25 \\
\\
26 \\
27 \\
\\
29 \\
\\
33 \\
35 \\
49 \\
53 \\
83\end{array}$ & $\begin{array}{r}22 \\
24 \\
32 \\
42 \\
46 \\
48 \\
52 \\
56 \\
59 \\
56 \\
60 \\
61 \\
64 \\
76 \\
82 \\
114 \\
130 \\
131 \\
210\end{array}$ & $\begin{array}{l}\beta^{+}, \gamma \\
\beta^{-}, \gamma \\
\beta^{-}, 0 \\
\beta^{-}, \gamma \\
\beta^{-}, \gamma \\
\beta^{+}, \mathrm{K}, \gamma \\
\beta^{+}, \mathrm{K}, \gamma \\
\beta^{-}, \gamma \\
\beta^{-}, \gamma \\
\beta^{+}, \gamma \\
\beta^{-}, \gamma \\
\beta^{+}, \mathrm{K}, 0 \\
\beta^{+}, \beta^{-}, \mathrm{K}, 0 \\
\beta^{-}, \gamma \\
\beta^{-}, \gamma \\
\beta^{-},(\gamma) \\
\beta^{-}, \gamma \\
\beta^{-}, \gamma \\
\beta^{-}, 0 \\
\end{array}$ & $\begin{array}{c}1100 \\
0.61 \\
14.5 \\
0.515 \\
85 \\
16 \\
6.5 \\
0.108 \\
47 \\
85 \\
1940 \\
0.142 \\
0.53 \\
1.12 \\
1.5 \\
50 \\
0.525 \\
8.0 \\
4.85\end{array}$ & $\begin{array}{l}0.225 \\
0.540 \\
0.695 \\
1.395 \\
1.117 \\
0.175 \\
0.085 \\
0.890 \\
0.120 \\
0.655 \\
0.099 \\
0.433 \\
0.120 \\
1.170 \\
0.150 \\
0.940 \\
0.270 \\
0.180 \\
0.330\end{array}$ & $\begin{array}{c}22000 \\
29 \\
885 \\
63 \\
870 \\
245 \\
48 \\
8.5 \\
496 \\
4900 \\
17000 \\
5.4 \\
5.6 \\
115 \\
20 \\
4150 \\
12.4 \\
127 \\
141\end{array}$ & $\begin{array}{l}6.3 \cdot 10^{-4} \\
0.68 \\
0.047 \\
0.74 \\
0.008 \\
0.042 \\
0.101 \\
0.998 \\
0.015 \\
0.008 \\
3.6 \cdot 10^{-4} \\
0.992 \\
0.73 \\
0.46 \\
0.37 \\
0.014 \\
0.73 \\
0.083 \\
0.133\end{array}$ & $\begin{array}{r}7.3 \\
5.1 \\
2.4 \\
2.1 \\
14.3 \\
9.7 \\
20.6 \\
11.8 \\
13.4 \\
2.6 \\
16.5 \\
18.7 \\
24.4 \\
1.9 \\
13.5 \\
1.7 \\
11.0 \\
9.4 \\
5.3\end{array}$ & $\begin{array}{c}197 \\
0.113 \\
3.6 \\
0.167 \\
30 \\
5.9 \\
2.6 \\
0.046 \\
21.3 \\
36.6 \\
895 \\
0.067 \\
0.26 \\
0.655 \\
0.95 \\
44 \\
0.53 \\
8.1 \\
7.85\end{array}$ & $\begin{array}{c}2.1 \\
6.4 \\
8.0 \\
19 \\
1.0 \\
2.8 \\
2.2 \\
14 \\
1.5 \\
7.0 \\
0.8 \\
5.5 \\
2.6 \\
15.7 \\
1.6 \\
9.4 \\
4.5 \\
2.2 \\
5.2\end{array}$ \\
\hline
\end{tabular}

Group $A: \bar{E}_{\beta}$ is known to an accuracy of a few per cent

\begin{tabular}{|c|c|c|c|c|c|c|c|c|c|c|}
\hline $\begin{array}{l}\text { C } \\
\text { S } \\
\text { Ca } \\
\text { Sr } \\
\text { Y } \\
\text { Sb } \\
\mathrm{Au}\end{array}$ & $\begin{array}{r}6 \\
16 \\
20 \\
38 \\
\\
39 \\
51 \\
79\end{array}$ & $\begin{array}{r}14 \\
35 \\
45 \\
89 \\
90 \\
90 \\
124 \\
198\end{array}$ & $\begin{array}{l}\beta^{-}, 0 \\
\beta^{-}, 0 \\
\beta^{-},(?) \\
\beta^{-}, 0 \\
\beta^{-}, 0 \\
\beta^{-}, 0 \\
\beta^{-}, \gamma \\
\beta^{-}, \gamma\end{array}$ & $\begin{array}{c}2.1 \cdot 10^{6} \\
88 \\
180 \\
55 \\
9000 \\
2.6 \\
60 \\
2.7\end{array}$ & $\begin{array}{l}0.05 \\
0.055 \\
0.10 \\
0.57 \\
0.22 \\
0.90 \\
0.66 \\
0.32\end{array}$ & $\begin{array}{c}9.2 \cdot 10^{6} \\
420 \\
1580 \\
2760 \\
17 \cdot 10^{4} \\
200 \\
3480 \\
76\end{array}$ & $\begin{array}{l}3.3 \cdot 10^{-7} \\
0.0079 \\
0.0039 \\
0.013 \\
8 \cdot 10^{-5} \\
0.24 \\
0.012 \\
0.23\end{array}$ & $\begin{array}{r}32 \\
30 \\
16 \\
3 \\
8 \\
2 \\
2.4 \\
5.7\end{array}$ & $\begin{array}{c}23.5 \cdot 10^{4} \\
24 \\
62 \\
38 \\
6200 \\
18 \\
57 \\
4.1\end{array}$ & $\begin{array}{l}0.24 \\
0.2 \\
0.8 \\
7 \\
2.2 \\
11 \\
12.3 \\
3.8\end{array}$ \\
\hline
\end{tabular}

Group B: $\overline{\mathrm{E}}_{\beta}$ is less accurately known than $\overline{\mathrm{E}}_{\beta}$ in Group A

Group C: $\overline{\mathrm{E}}_{\beta}$ includes the total localized x-radiation following decay by electron capture

\begin{tabular}{l|l|l|l|r|l|l|l|l|r|r}
\hline $\mathrm{Mn}$ & 25 & 54 & $\mathrm{~K}, \gamma$ & 310 & 0.0054 & 147 & 0.0022 & 340 & 128 \\
$\mathrm{Fe}$ & 26 & 55 & $\mathrm{~K}, \gamma$ & 1500 & 0.0059 & 780 & $4.6 \cdot 10^{-4}$ & 280 & 633 & \\
$\mathrm{Co}$ & 27 & $\mathbf{5 8}$ & $\beta^{+}, \mathrm{K}, \gamma$ & 65 & 0.035 & 20 & $\mathbf{0 . 0 1 2}$ & 415 & 29 & 1.5 \\
$\mathrm{Zn}$ & 30 & $\mathbf{6 5}$ & $\beta^{+}, \mathrm{K}, \gamma$ & 250 & 0.01 & 180 & $\mathbf{0 . 0 0 3}$ & 185 & 124 & 1.2 \\
\hline
\end{tabular}

Group D: $\overline{\mathrm{E}}_{\boldsymbol{\beta}}$ consists of part of the radiation released in the decay by electron capture

\begin{tabular}{l|l|r|l|l|l|l|l|l|l|l}
\hline $\mathrm{Y}$ & 39 & 86 & $\mathrm{~K}, \gamma$ & 105 & 0.005 & 46 & 0.007 & 310 & 69 \\
$\mathrm{In}$ & 49 & 111 & $\mathrm{~K}, \gamma$ & 2.7 & 0.0058 & 1.4 & 0.23 & 310 & 2.3 & 0.01 \\
\hline
\end{tabular}

The values of $K_{\beta}$ and $S_{\beta}$ are based on uniform and biologically stable concentrations of radioelements distributed in tissues of linear dimensions large as compared to the range of the beta particles. The sign " 0 " under the heading "Radiation" indicates the absence of nuclear gamma rays.

$\overline{\mathrm{E}}_{\beta}$ is the average energy per disintegration.

$\mathrm{K}_{\beta}=88 \overline{\mathrm{E}}_{\beta} \mathrm{T}$ is the radiation dose expressed in equivalent roentgens due to beta rays emitted during the complete disintegration of $1 \mu \mathrm{c}$ of radioelement per gram of tissue.

$f_{d}=\left(1-e^{-0.693 / T}\right)$ is the fraction of the entire quantity of isotope which disintegrates in 24 hours.

$S_{\beta}=\frac{100}{K_{\beta} \times f_{d}}$ is the concentration of radioisotope expressed in $\mu \mathrm{c}$ per $\mathrm{kg}$ which will deliver a dose of 0.1 e.r. to tissue during the first 24 hours of exposure. 
TABLE II

Physical data pertaining to calculations of radiation dosage resulting from gamma rays

\begin{tabular}{|c|c|c|c|c|c|c|c|c|c|c|}
\hline \multirow{2}{*}{$\begin{array}{c}\text { Ele- } \\
\text { ment }\end{array}$} & \multirow{2}{*}{$\mathbf{Z}$} & \multirow{2}{*}{$\mathbf{A}$} & \multirow{2}{*}{ Radiation } & \multirow{2}{*}{$\underset{\substack{\text { Half life } \\
\text { in hours }}}{T}$} & \multicolumn{2}{|r|}{$\mathrm{E}_{\mathbf{j}}$ in $\mathrm{Mev}$} & \multirow{2}{*}{$\underset{\substack{\text { at } \\
\mathrm{mr} / \boldsymbol{m c}-\mathrm{mr}}}{\mathrm{I}_{\boldsymbol{r}} \mathrm{cm}}$} & \multirow{2}{*}{$\underset{\text { at } \mathbf{r} / \boldsymbol{M c d}}{\mathbf{K} \mathbf{c m}}$} & \multirow{2}{*}{$\begin{array}{c}\text { fd } \\
\text { fraction } \\
\text { disintegr. } \\
\text { per day }\end{array}$} & \multirow{2}{*}{$\begin{array}{c}\stackrel{\mu}{\text { per }} \\
\text { cm } \\
\times 100\end{array}$} \\
\hline & & & & & $\begin{array}{l}\text { Annihila- } \\
\text { tion } \\
\text { radiation }\end{array}$ & Nuclear gamma radiation & & & & \\
\hline
\end{tabular}

Group A: elements not decaying by electron capture, or $x$-ray emission following electron capture so soft that it can be treated like beta radiation and hence making no significant contribution to $I_{\gamma}$

\begin{tabular}{|c|c|c|c|c|c|c|c|c|c|c|c|c|c|}
\hline $\begin{array}{l}\mathrm{Na} \\
\mathrm{K} \\
\mathrm{Sc} \\
\mathrm{V} \\
\mathrm{Mn} \\
\mathrm{Fe} \\
\mathrm{Co} \\
\mathrm{Cu} \\
\mathrm{As} \\
\mathrm{Br} \\
\mathrm{Sb}\end{array}$ & $\begin{array}{l}11 \\
19 \\
21 \\
23 \\
25 \\
26 \\
27 \\
29 \\
33 \\
35 \\
51\end{array}$ & $\begin{array}{r}22 \\
24 \\
42 \\
46 \\
48 \\
52 \\
56 \\
59 \\
56 \\
60 \\
61 \\
64 \\
76 \\
82 \\
124 \\
130 \\
131 \\
198\end{array}$ & $\begin{array}{l}\beta^{+}, \gamma \\
\beta^{-}, \gamma \\
\beta^{-}, \gamma \\
\beta^{-}, \gamma \\
\beta^{+}, \mathcal{K}, \gamma \\
\beta^{+}, \mathbf{K}, \gamma \\
\beta^{-}, \gamma \\
\beta^{-}, \gamma \\
\beta^{+}, \gamma \\
\beta^{-}, \gamma \\
\beta^{+}, \mathbf{K}, 0 \\
\beta^{+}, \beta^{-}, \mathbf{K}, 0 \\
\beta^{-}, \gamma \\
\beta^{-}, \gamma \\
\beta^{-}, \gamma \\
\beta^{-}, \gamma \\
\beta^{-}, \gamma \\
\beta^{-}, \gamma\end{array}$ & \begin{tabular}{|c|}
26500 \\
14.7 \\
12.4 \\
2040 \\
384 \\
156 \\
2.59 \\
1128 \\
2040 \\
46500 \\
3.4 \\
12.8 \\
26.8 \\
36 \\
1440 \\
12.6 \\
192 \\
65
\end{tabular} & $\begin{array}{l}0.511(2) \\
0.511(1.16) \\
0.511(0.7) \\
0.511(2) \\
0.511(1.56) \\
0.511(0.38)\end{array}$ & $\begin{array}{l}1.30(1) \\
1.38(1) \\
1.51(0.25) \\
0.90(1) \\
0.98(1) \\
0.736(1) \\
1.77(0.3) \\
1.1(0.5) \\
0.845(1) \\
1.16(1) \\
\\
0.55(0.37) \\
0.547(1) \\
0.6(1) \\
0.416(0.55) \\
0.080(.01) \\
0.40(1)\end{array}$ & $\begin{array}{l}2.76(1) \\
1.12(1) \\
1.33(1) \\
0.94(1) \\
2.06(0.2) \\
1.3(0.5) \\
1.26(1) \\
1.32(1) \\
\\
1.20(0.12) \\
0.787(1) \\
1.7(0.5) \\
0.537(1) \\
0.363(.8)\end{array}$ & $\begin{array}{l} \\
1.75(0.01) \\
1.35(1) \\
0.667(1) \\
0.638(.15)\end{array}$ & $\begin{array}{l}0.744(1) \\
0.283(.06)\end{array}$ & $\begin{array}{c}13.2 \\
19.1 \\
1.95 \\
11.4 \\
16.3 \\
19.5 \\
9.4 \\
6.55 \\
17.95 \\
13.5 \\
4.8 \\
1.2 \\
2.2 \\
15.1 \\
7.9 \\
13.05 \\
2.37 \\
2.4\end{array}$ & $\begin{array}{c}500 \\
0.40 \\
0.035 \\
33.5 \\
9.0 \\
4.4 \\
0.035 \\
10.7 \\
37.2 \\
900 \\
0.024 \\
0.022 \\
0.083 \\
0.79 \\
16.4 \\
0.237 \\
0.66 \\
0.22\end{array}$ & $\begin{array}{l}6.3 \cdot 10^{-1} \\
0.68 \\
0.74 \\
0.008 \\
0.042 \\
0.101 \\
0.998 \\
0.015 \\
0.008 \\
3.6 \cdot 10^{-4} \\
0.992 \\
0.73 \\
0.46 \\
0.37 \\
0.012 \\
0.73 \\
0.083 \\
0.23\end{array}$ & $\begin{array}{l}3.2 \\
2.5 \\
2.9 \\
3.2 \\
3.2 \\
3.2 \\
2.7 \\
\mathbf{3 . 0} \\
3.2 \\
3.0 \\
\mathbf{3 . 4} \\
\mathbf{3 . 4} \\
\mathbf{3 . 0} \\
\mathbf{3 . 2} \\
\mathbf{3 . 2} \\
\mathbf{3 . 4} \\
\mathbf{3 . 0} \\
\mathbf{3 . 4}\end{array}$ \\
\hline
\end{tabular}

Group B: elements with $x$-ray emission following electron capture whose contribution to $I_{\boldsymbol{\gamma}}$ is not negligible

\begin{tabular}{|c|c|c|c|c|c|c|c|c|c|c|c|c|}
\hline $\begin{array}{l}\text { Mn } \\
\text { Fe } \\
\text { Co } \\
\text { Zn } \\
\text { Y } \\
\text { In }\end{array}$ & $\begin{array}{l}25 \\
26 \\
27 \\
30 \\
39 \\
49\end{array}$ & $\begin{array}{r}54 \\
55 \\
58 \\
65 \\
86 \\
111\end{array}$ & $\begin{array}{l}\mathbf{K}, \boldsymbol{\gamma} \\
\mathbf{K}, \boldsymbol{\gamma} \\
\boldsymbol{\beta}^{+}, \mathbf{K}, \boldsymbol{\gamma} \\
\boldsymbol{\beta}^{+}, \mathbf{K}, \boldsymbol{\gamma} \\
\mathbf{K}, \boldsymbol{\gamma} \\
\mathbf{K}, \boldsymbol{\gamma}\end{array}$ & $\begin{array}{r}7450 \\
36000 \\
1560 \\
6000 \\
2530 \\
65\end{array}$ & $\begin{array}{l}0.511(0.3) \\
0.511(0.03)\end{array}$ & $\begin{array}{l}0.835(1) \\
0.07\left(2 \cdot 10^{-6}\right) \\
0.805(1) \\
1.14(0.46) \\
0.908(1) \\
0.173(1)\end{array}$ & $\begin{array}{l}1.89(1) \\
0.247(1)\end{array}$ & $\begin{array}{l}{[0.0054(1)]} \\
{[0.0059(1)]} \\
0.0064(0.85)] \\
0.008(0.99)] \\
0.0142(1)] \\
{[0.0231(1)]}\end{array}$ & $\begin{array}{c}4.9+[11] \\
5[10] \\
5.7+[7] \\
3.0+[5] \\
14.4+[3.1] \\
2.3+[1.4]\end{array}$ & $\begin{array}{l}\frac{52}{12.8} \\
26 \\
52.5+[10.3] \\
0.22+[0.13]\end{array}$ & $\begin{array}{l}0.0022 \\
4.6 \cdot 10-4 \\
0.012 \\
0.003 \\
0.007 \\
0.23\end{array}$ & $\begin{array}{l}3.2 \\
3.2 \\
3.3 \\
\text { 3.0 } \\
\text { 3.2 } \\
\mathbf{3 . 0}\end{array}$ \\
\hline
\end{tabular}

The sign " 0 " under the heading "Radiation" indicates the absence of nuclear gamma rays. The column headed "Annihilation radiation" refers to positron-electron recombination, the column headed "Nuclear gamma radiation" refers to gamma rays originating in the disintegrated nucleus. The numbers in parentheses indicate the number of photons of the particular energy that are released per disintegration.

In Group B, the numbers in square brackets pertain to $x$-ray emission following electron capture and, because of the short range of the radiation, they should not be used in computing $\gamma$-ray dosage. In practice, this type of dose computation is amenable to the simpler formulae used for $\beta$-rays (see Group C in Table I).

$\mathrm{I}_{\boldsymbol{\gamma}}$ is the exposure in roentgens at $1 \mathrm{~cm}$ distance in air from an unfiltered point source of $1 \mathrm{mc}$, for one hour; or milli-roentgens per microcurie-hour (see formula IIIa).

$\mathrm{K}_{\gamma}=1.44 \mathrm{tI}_{\gamma} \times 10^{-3}$ is the number of roentgens, per microcurie destroyed, at $1 \mathrm{~cm}$ distance in air from an unfiltered point source.

$f_{d}=\left(1-e^{-0.693 / T}\right)$ is the fraction of the entire quantity of isotope which disintegrates in 24 hours. ( $T$ is the half life in days.)

$\mu=$ true absorption coefficient of the $\boldsymbol{\gamma}$-radiation in water.

column. The last column gives the ranges in water for the most energetic beta particles of each beta ray spectrum for the different isotopes. It should be noted that the column for $\mathrm{K}_{\beta}$ gives immediately the dose in equivalent roentgens for each microcurie completely disintegrating within a gram of tissue.

Gamma Ray Emitters. When a substance is a gamma ray emitter, the problem of dosage determination is more complicated. The rays released in a given gram of tissue produce only a small amount of ionization there; most of their energy is expended elsewhere along their paths. The problem becomes somewhat analogous to that of interstitial radium gamma ray dosage, except that instead of discrete sources one is confronted with extended ones.

At a given point the total dose $D_{\gamma}$, due to gamma rays emitted by the complete disintegration of a radioelement biologically stable and present in a uniform concentration of $\mathbf{C}$ microcuries per gram of tissue, is given by

$$
\mathrm{D}_{\gamma}=\mathrm{K}_{\gamma} \mathrm{Cg} \text { roentgens }
$$

where

$$
\mathrm{K}_{\gamma}=1.44 \mathrm{tI}_{\gamma} \times 10^{-3}
$$

IIIa

The dose delivered in one day is

$$
d_{\gamma} \text { (day) }=D_{\gamma} f_{d} \text {, }
$$

$f_{d}$ having the meaning expressed above. $K_{\gamma}$ expresses the number of roentgens at $1 \mathrm{~cm}$ distance in air due to the complete disintegration of an unfiltered point source of $1 \mu c ; 1.44 \times t$ is the average life in hours, $I_{\gamma}$ the dose-rate in roentgens per hour at $1 \mathrm{~cm}$ in air from an unfiltered point source of $1 \mathrm{mc}$. The quantity $\mathrm{g}$ in equation III is a geometrical factor depending on the location of the given point, the size and shape of the tissue mass containing the isotope, and on the absorption coefficient $\mu$ of the gamma rays in tissue. The values of $I_{\gamma}$ and $K_{\gamma}$ together with other pertinent information for gamma ray emitting radioisotopes are given in Table II.

Safe Tracer Concentration. In the main Tables I and II are self explanatory. Atten- 
tion should be directed to column 9 in Table I, headed $\mathrm{S}_{\beta}$, which indicates the "safe tracer concentration," that is, the number of $\mu \mathrm{c}$ per $\mathrm{kg}$ of tissue weight which will result in a whole tissue dose of $0.1 \mathrm{r}$ the first day, due to the beta rays alone. (The gamma ray contribution will be discussed below.) In the case of a short-lived element, the dose on succeeding days will quickly decrease to the vanishing point, while for longlived substances it will continue at an appreciable level for some time. This criterion of "safe dose" is decidedly conservative. One might prefer to choose such a level as $1 \mathrm{r}$ in 10 days or some other value based on a longer period of time. This might avoid complications due to various half lives. However, the present familiar idea of safety is based on daily dose; hence that has been used here. It is not to be assumed that larger tracer doses should never be administered. It is sometimes entirely justifiable to use considerably higher doses in diagnostic problems.

Distribution of the Radiation in Tissue. The physical data presented enable the experimenter to calculate the actual dose delivered to a tissue

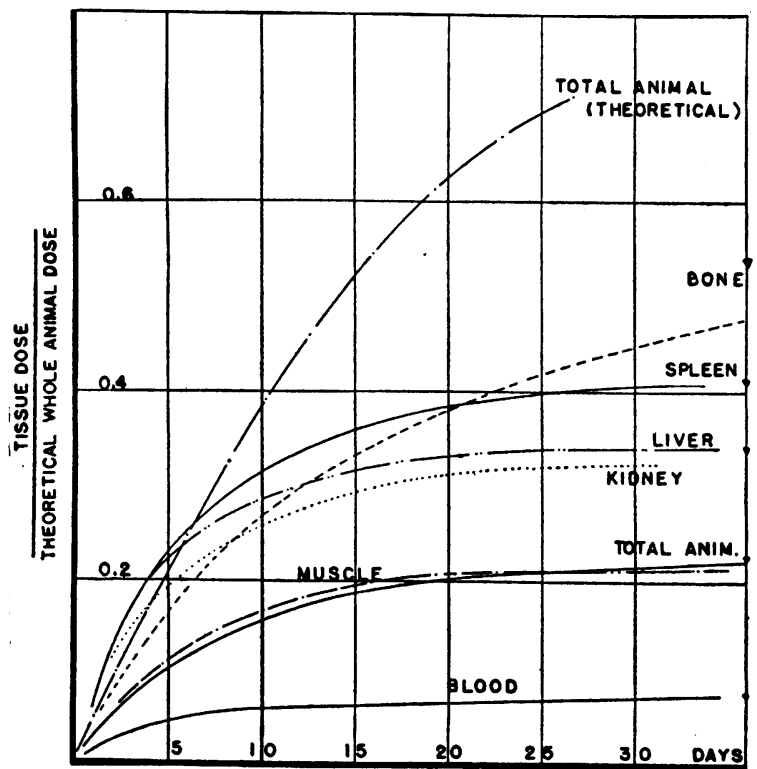

Fig. 1. Radiation Dosage Due to the Beta Ray Activity of $\mathrm{P}^{22}$ in Different Tissues in Mice As a Function of Time

The points marked on the right margin are the actual tissue doses obtained by extrapolation to infinite time. Theoretical whole animal dose equals $K_{\beta}$ times the number of microcuries administered divided by the total weight of the animal. or individual whenever the isotope concentration $\mathrm{C}$ is known as a function of time. This depends on the amount of isotope administered, the species and metabolic state of the test animal, the mode of administration, the chemical form under which the radioelement is given, etc.

Physiological information of this nature is of great importance; the literature shows that a good deal of animal work has been done on the relative uptake of various isotopes by different tissues at different times. As an example, in Figure 1 are shown the relative radiation doses delivered in different tissues in mice injected intraperitoneally with $\mathrm{P}^{32}$ in the form of $\mathrm{Na}_{2} \mathrm{HPO}_{4}$. The animals were sacrificed at various times after the administration of the material, and the concentration of $\mathrm{P}^{32}$ was determined for the various tissues and organs. By adding graphically the daily doses as expressed by equation II it was possible to calculate the dose of radiation received by each tissue as a function of time (3). Similar calculations were made for the whole body assuming uniform distribution. The "theoretical" whole animal dose $^{4}$ after complete disintegration of the isotope was taken as 100 per cent, and all other tissue doses referred to this value. Thus at the end of three weeks, 64 per cent of the theoretical complete dose had been delivered; but all tissues tested, except the bone, had received already practically all their radiation because most $\mathrm{P}^{32}$ had disappeared. The liver, for example, had received about 33 per cent of the theoretical uniform dose. At that time the bone had received 39 per cent; but in the bone the dosage increased to 48 per cent at the end of 36 days.

No tissue actually attained the theoretical dose or would have attained it after longer periods of time because of biological elimination. From the curves, the actual tissue dosage per $\mu \mathrm{c}$ of $\mathrm{P}^{32}$ thus administered in a mouse of 25 grams can now be calculated. The total animal concentration would be $0.04 \mu \mathrm{c}$ per gram and the "theoretical" total animal dose $\mathrm{D}_{\beta}=\mathrm{K}_{\beta} \times 0.04$ $=885 \times 0.04=35.4$ e.r. $\left(K_{\beta}\right.$ from Table $\left.\mathrm{I}\right)$. The liver, then, at the end of three weeks would

"By "theoretical" whole animal dose is meant the dose $D_{\beta}$ which would have been obtained in the animal after complete disintegration of the isotope on the assumption of uniform concentration in the animal and of total lack of biological elimination. 
have received 33 per cent of this value or $12 \mathrm{r}$; similarly the bone at 36 days would have had $0.48 \times 35.4=17 \mathrm{r}$.

It is recognized that with $\mathrm{P}^{32}$ in mice these determinations are not as accurate as one would wish because the linear dimensions of most organs are smaller than the range of a considerable portion of the beta particles emitted by $\mathrm{P}^{32}$. Similar information in larger animals would yield more reliable figures. Conversely this type of calculation would be fairly accurate even in a small animal, as the mouse, if soft beta ray emitters $\left(\mathrm{H}^{3}, \mathrm{C}^{14}, \mathrm{~S}^{35}\right.$, etc.) were used.

When working with humans it is not possible in general to study concentrations throughout the body and their variations with time by in vivo measurements; the extreme concentration of iodine in the thyroid is an exception. For most isotopes information must be obtained from biopsy and autopsy measurements and hence the data are meager; moreover they are scattered through various publications which were often not prepared with this point in mind. Accordingly it has happened too often that the published results lack some essential fact, such as the actual weight of the individual. It is to be hoped that more of this information will be forthcoming. In the meanwhile, it is wise to adopt a conservative attitude in dealing with humans whenever physiological information is lacking. This can be done by assuming that no biological elimination takes place.

Differential Absorption Ratio. To take into account the differences in uptake which lead to differences in dose for the various tissues, it is convenient to express the concentration in terms of a "differential absorption ratio" (D.A.R.). For any tissue, this is the ratio of concentration of an isotope in that tissue to the average concentration in the body (neglecting excretion). Thus under the assumption just made if a particular tissue has a D.A.R. of 1 , it receives the same dose of radiation as the average of the whole body. On the other hand, if it has a D.A.R. of 10 , it receives ten times as much radiation as the average.

In calculating the safe doses for tracers, it is highly desirable to have some idea of the range of the D.A.R.'s. The safe dose is assumed to be 0.1 per day for the entire body; if a certain tissue has a D.A.R. of 10, it would have received $1 \mathrm{r}$ while the rest of the body received $0.1 \mathrm{r}$. This might lead to undesirable irradiation of certain tissues or organs from a dose believed safe otherwise.

The procedure outlined above needs clarification. In general, single tissues and the whole body have different rates and modes of elimination; hence the tissue D.A.R. will vary with time. The question then arises as to the time at which D.A.R.'s have significance in determination of tissue dosage. Evidently the D.A.R. will be too low when taken too soon after the isotope administration because the concentrations have not yet stabilized. Likewise adoption of the D.A.R. after several half lives will have little or no significance because most of the isotope has disintegrated. One useful index, whenever the isotope reaches the body tissues through the circulatory system, could be the stabilization of the plasma concentration. No general rule, however, can be given and good judgment is of paramount importance.

Effective Half Life. In instances of extreme concentrations as in the case of radioiodine $\mathrm{I}^{\mathbf{1 3 1}}$ administered to humans in the form of $\mathrm{KI}$ or $\mathrm{NaI}$, greater accuracy can be obtained. It will be noted that the formula I for the dose, $D_{\beta}$, contains the half life of the element. If the amount of iodine in the gland decreases both by decay and by excretion, the effective half life will be less than the physical. Such effects can be determined only by actual measurements. In this particular problem, counts are made at intervals with a Geiger counter in a fixed position over the thyroid gland. If there were no excretion of the material from the gland, these counts should decrease exactly in accordance with the physical decay curve for the iodine; that is, for $I^{131}$ they should be at half their initial value after eight days, one-fourth at 16 days, etc. Actually, they decrease exponentially but more rapidly, half lives as short as two days having been encountered in practice. It is evident that the use of this number instead of 8 in equation I results in a decrease of 75 per cent in the administered dose, an amount which is clinically significant in therapeutic work. It would be now possible to calculate from formula $I$ the dose delivered under normal conditions if the 
initial concentration $\mathrm{C}$ were known. This can be determined either by actual biopsy or "guessed" by estimate of the gland weight and measurements of the radioactive content of the gland by proper in vivo observations.

It is evident from Table $I$ that the actual amounts of the safe concentrations in tissue do not vary very greatly; it must be realized that the intervals at which they can be repeated do. A reasonable interval between full tracer doses of any particular element would be four or five half lives, unless the material has been shown to be excreted fairly completely in a shorter period. If no significant excretion occurs, a tracer of $\mathrm{Na}^{24}$ could be repeated within about three days, while $P^{32}$ should not be repeated in less than about two months, and $\mathrm{Ca}^{45}$ not before two years have elapsed.

It should be mentioned in this connection that the safe doses listed here are calculated on the assumption that the individual is receiving no radiation from any other source. Extensive radiographic or fluoroscopic procedures may result in an appreciable dose of radiation, and such possibilities must not be overlooked.

\section{TRACER ISOTOPES-EXAMPLES}

In order to illustrate the use of the material presented in this paper sample calculations will be given for some isotopes commonly used in tracer experiments and in therapy. These will be presented in order of the complexity of their spectra.

\section{Radioactive phosphorus-P32-(Beta particles only)}

If the isotope were evenly distributed throughout the body and no elimination took place the values of Table I would be directly applicable. Thus, if $2.4 \mu \mathrm{c}$ per $\mathrm{kg}$ gives a dose of 0.1 e.r., an initial radiation dose of $d$ e.r. per day will require a concentration $\mathrm{x} \mu \mathrm{c}$ per $\mathrm{kg}$ such that

namely:

$$
\text { 2.4:0.1 = } \mathrm{x}: \mathrm{d} \text {, }
$$

$$
\mathrm{x}=2.4 \mathrm{~d} / 0.1=24 \mathrm{~d} \mu \mathrm{c} \text { per } \mathrm{kg} \text {. }
$$

If a total radiation dose $D_{\beta}$ (e.r.) is to be given to a tissue, the concentration in that tissue should be such that

$$
\mathrm{D}_{\beta}=\mathrm{K}_{\beta} \mathrm{C} \quad \text { or } \quad \mathrm{C}=\mathrm{D} / 885 \mu \mathrm{c} \text { per gram. }
$$

As already mentioned, the most exhaustive information on the distribution of this isotope in mice (3) shows that the highest radiation dose is given to bone, followed in order by spleen, liver, kidney, muscle and blood. In general, the limited information on adult humans obtained for the major part from autopsies of leukemic patients (4-9), does not contradict the results in mice, provided that only non-infiltrated tissue obtained from patients given single doses of $\mathrm{P}^{32}$ be taken into consideration. Limited data on non-irradiated surgical material are also available (10). The most reliable D.A.R.'s on bone are of the order of unity though wide variations are noted not only among individuals but also among portions of the same bone $(5,10)$. The absolute value of the D.A.R.'s for human bone -as in the case of mice-seems to bear no detectable relation to the time elapsed between administration and assay; this points to a slow "net" elimination of $\mathrm{P}^{32}$ from bone.

The highest D.A.R. reported on human marrow $(7,10)$ devoid of leukemic infiltration can also be taken of the order of unity for the first few days following $\mathrm{P}^{32}$ administration. Data on sternal aspiration (7), however, are decidedly lower, being much closer to that of blood. The latter in humans receives "apparent" doses of the order of 20 per cent of the theoretical whole body dose (11). It seems therefore that doses of the order of $2.4 \mu \mathrm{c}$ per $\mathrm{kg}$ of body weight can be safely administered, though they may produce wholly transitory but definite biological effects, such as those reported by Low-Beer and Treadwell (12) for concentrations of 6-9 $\mu \mathrm{c}$ per $\mathrm{kg}$ of body weight.

If $\mathrm{P}^{32}$ is administered intravenously in insoluble form the deposition in the liver and spleen is likely to be very marked (13). The authors report 80-89 per cent in the liver (dog and mouse); if this were to obtain in humans the D.A.R. would be:

$$
\text { D.A.R. }=\frac{\frac{\mu c \text { in liver }}{\text { liver weight }}}{\frac{\mu \mathrm{c} \text { administered }}{\text { body weight }}}=\frac{0.89 \times 70}{1.7}=36.7 \text {, }
$$

$1.7 \mathrm{~kg}$ being the weight of the average human liver (14). In this case the maximum permissible concentration would be

$$
2.4 / 36.7=0.066 \mu \mathrm{c} \text { per } \mathrm{kg} \text { of body weight }
$$
or a total tracer dose of $0.066 \times 70=4.6 \mu \mathrm{c}$ of $\mathrm{P}^{3 s}$ for $\mathrm{a}$ $70 \mathrm{~kg}$ man. 


\section{Radioactive strontium-Sr ${ }^{89}$-(beta particles only)}

Work on animals (15) indicates that this isotope is highly concentrated in the bone. Human material has been reported by Treadwell et al. (16) following intravenous injections. Their data point to a maximum D.A.R. in the epiphysis of bone of 13.2, and an unweighted average of 8.3 for bone, mostly in young subjects. A trend of D.A.R. change with time is not apparent. On the basis of this, the tolerance concentration would be, since $S_{\beta}=3 \mu \mathrm{c}$ per $\mathrm{kg}$,

$\mathrm{S}_{\beta} / 8.3=3 / 8.3=0.4 \mu \mathrm{c}$ per $\mathrm{kg}$ of body weight.

\section{Radioactive calcium-Ca ${ }^{45}$-(beta particles only)}

The relative concentrations of this isotope in human tissue have not been reported to date. Work on mice shows that the D.A.R. for Ca in animal bone is approximately twice that for Sr (15). Hence, if this ratio holds also for humans one should expect a D.A.R. of about $8.3 \times 2=16.6$.

It follows from Table $I$ that the tolerance concentration would be, since $S_{\beta}=16 \mu$ c per $\mathrm{kg}$,

\section{$16.0 / 16.6 \approx 1.0 \mu \mathrm{c}$ per $\mathrm{kg}$ of body weight.}

It should be noted that if calcium were deposited exclusively in the human skeleton and the distribution were uniform the D.A.R. would be 10 (weight of skeleton $=10$ per cent of body weight); nevertheless, the most active parts of the bone concentrate it more and hence the higher value adopted is not unreasonable.

\section{Radioactive sodium-Na $\mathrm{Na}^{24}$-(beta and gamma radiation)}

This isotope of sodium, administered orally or intravenously, is eliminated in very small amounts during times comparable to its half life. Since it is distributed rather uniformly throughout the body $(17,18)$, computation of beta ray dosage can be made on the basis of D.A.R. $=1$. The factor $S_{\beta}$ of Table I can be applied directly in the case of small animals where the beta rays account for most of the radiation dose, the factor $\mathrm{g}$ in the gamma ray formula being very small. For larger animals and humans, however, the gamma ray contribution cannot be neglected. In this case dosage calculations become more involved.
As pointed out above the contribution of gamma rays to the daily tissue dose is

$$
\begin{aligned}
\mathrm{d}_{\gamma}= & \mathrm{C}_{\gamma} \mathrm{Kf}_{\mathrm{d}} \mathrm{g} \text { roentgens where } \\
\mathrm{C}= & \text { concentration in } \mu \mathrm{c} \text { per gram of tissue } \\
\mathrm{K}_{\boldsymbol{\gamma}}= & \text { roentgens at } 1 \mathrm{~cm} \text { per } \mu \mathrm{cd} \\
\mathrm{f}_{\mathrm{d}}= & \text { fraction of atoms destroyed in one day } \\
\mathrm{g}= & \text { geometrical factor which is a function of the size } \\
& \quad \text { and shape of the tissue volume and the penetra- } \\
& \quad \text { tion of the radiation. }
\end{aligned}
$$

For purposes of calculation one may assume that the human trunk is a cylinder of radius $R=20 \mathrm{~cm}$ and height $2 Z=60 \mathrm{~cm}$, and that $\mathrm{C}$ is constant throughout. Under these conditions the highest dose is delivered at the midpoint of the axis and $\mathrm{g}$ can be expressed with sufficient approximation (1) as $\mathrm{g}=314-4140 \mu$ where $\mu$ is the absorption coefficient of the gamma rays in tissue. For the gamma rays from sodium (see Table II) the values of $\mu$ are 0.0296 and 0.0233 per $\mathrm{cm}$, respectively. An average $\boldsymbol{\mu}=\mathbf{0 . 0 2 5}$ may be assumed for the present calculation and hence $g=210.5$. Substituting for $K_{\gamma}$ and $f_{d}$ the values from Table II, one obtains:

$\mathrm{d}_{\gamma}=0.40 \times 0.68 \times 210.5 \mathrm{C}=58.0 \mathrm{C} \mathrm{r}$ per day at the center of the trunk if $C$ is given in $\mu \mathrm{c}$ per gram of tissue.

Similarly (Table I):

$d_{\beta}=29 \times 0.68 \times C=19.7 \mathrm{C}$ e.r. per day if $\mathrm{C}$ is given in $\mu \mathrm{C}$ per gram of tissue.

Hence the total dose for the first day is $d_{\beta+\gamma}=77.7 \mathrm{C}$. The total dose $D_{\beta+\gamma}$ can be obtained from this figure. Since 68 per cent of the atoms disintegrate during the first day, $77.7 \mathrm{C}$ is 68 per cent of the total dose. Hence the latter is:

$$
D_{\beta+\gamma}=\frac{100}{68} \times 77.7=114 \text { C e.r. }
$$

For the tolerance dose of $0.1 \mathrm{r}$ per day,

$$
\mathrm{S}_{\beta}=\frac{0.1}{77.7}=0.0013 \mu \mathrm{c} \text { per gram }
$$

or $1.3 \mu \mathrm{c}$ per $\mathrm{kg}$ of body weight.

\section{Radioactive sodium- $\mathrm{Na}^{22}-($ beta and gamma radiation)}

The computation of tolerance dose follows closely that illustrated for $\mathrm{Na}^{24}$ except for the numerical values involved. Thus, $\mathrm{K}_{\gamma}=500$; $f_{d}=6.3 \times 10^{-4} ; g=(314-4140 \times 0.032)$ $=181$, since $\mu$ can be considered to be 0.032 for the purpose of this approximation.

\footnotetext{
Hence,

$\mathrm{d}_{\boldsymbol{\gamma}}=500 \times 6.3 \times 10^{-4} \times 181=57 \mathrm{C}$ at the center of the trunk and

$\mathrm{d}_{\beta}=22,000 \times 6.3 \times 10^{-4} \times \mathrm{C}=14 \mathrm{C}$

$d_{\beta+\gamma}=71 C$ e.r. per day if $C$ is in $\mu c$ per gram of tissue

$D_{\beta+\gamma}=11.3 \times 10^{4} \mathrm{C}$ e.r.

$\mathrm{S}_{\beta+\gamma}=\frac{0.1}{71}=0.0014 \mu \mathrm{c}$ per gram $=1.4 \mu \mathrm{c}$ per $\mathrm{kg}$ of tissue or body weight since $\mathrm{C}$ is considered constant throughout the body.
} 
This dose $\left(D_{\beta+\gamma}\right)$ would be delivered over a period of years if there were no excretion of the sodium. However, experimentally the material has a physiological (or effective) half life of the order of one month or less, in normals and in individuals with congestive heart failure (19). In these cases the actual $D_{\beta+\gamma}$ is nearer to $3,000 \mathrm{C}$. For nephrotics excretion is very much slower, and the dose of radiation would be correspondingly larger.

These two sodium isotopes offer a good illustration of the point made above regarding the repetition of tracer doses. Although the doses of the two isotopes which will give 0.1 e.r. the first day are essentially the same, the total dose from this amount of $\mathrm{Na}^{24}$ may be repeated much sooner.

\section{Radioactive potassium- $K^{42}$-(beta and gamma radiation)}

Under the same assumptions of distribution and elimination as in the case of $\mathrm{Na}^{24}$,

$$
\begin{aligned}
& \qquad \begin{aligned}
\mathrm{K}_{\gamma}= & 0.0348, \mathrm{f}_{\mathrm{d}}=0.739 \text { and } \mathrm{g}=198 \\
\mathrm{~d}_{\gamma}= & 0.035 \times 0.74 \times 198 \times \mathrm{C}=5.2 \mathrm{C} \text { at the center of } \\
& \text { the trunk, } \mathrm{d}_{\beta}=63 \times 0.74 \times \mathrm{C}=46.5 \mathrm{C}
\end{aligned} \\
& \text { hence } \\
& \mathrm{d}_{\beta+\gamma}= \\
& \begin{array}{l}
51.7 \times \mathrm{C} \text { e.r. per day }(\mathrm{C} \text { in } \mu \mathrm{C} \text { per gram }) \\
\mathrm{D}_{\beta+\gamma}=70 \mathrm{C} \text { e.r. }
\end{array}
\end{aligned}
$$

and finally

$S_{\beta+\gamma}=\frac{0.1}{51.7}=1.9 \mu \mathrm{c}$ per $\mathrm{kg}$ of body weight.

\section{Radioactive iodine-I $I^{130}$ - (beta and gamma radia- tion)}

The distribution of radioiodine in the body is characterized by a high and relatively stable deposition in normal thyroid tissue and a low concentration in the rest of the body.

Assays in rabbits and rats (20) show that at various times after administration of iodide, most known radiosensitive tissues show average concentrations of the isotope close to that of blood. Unfortunately no information is available for the marrow. The concentration in thyroid tissue, however, is so markedly different from the rest of the body that the dosage problem assumes different aspects according to whether tracer studies or radical therapeutic procedures are contemplated. Full discussion of the latter is outside the scope of the present paper $(21,22)$.
In the case of tracer studies it is of interest to calculate the dose to the thyroid itself, since it is very unlikely that the radiosensitivity of any other tissue in the body is such as to overcome the very large thyroid D.A.R. From Table I the beta ray daily dose is readily calculated.

$$
\mathrm{d}_{\beta}=12.4 \times 0.73 \times \mathrm{C}=9.1 \mathrm{C}
$$

For the calculation of $D_{\gamma}$, from Table II $K_{\gamma}=0.237$; $f_{d}=\mathbf{0 . 7 3}$. The geometrical factor $g$ is very different from the cases of sodium and potassium in which the whole body dosage was considered. The usual gland (about 25 grams) can be represented by two separate spheres of radius equal to only $1.4 \mathrm{~cm}$ and, for this calculation, we may neglect the influence of the radiation from one lobe on the other. In this case $g=\frac{4 \pi\left(1-\mathrm{e}^{-\mu_{\mathrm{R}}}\right)}{\mu} \sim 4 \pi \mathrm{R}$ $=17.6$ since $\mu \mathrm{R}$ is very small. It follows that

$$
\mathrm{d}_{\boldsymbol{\gamma}}=0.237 \times 0.73 \times 17.6=3.0 \mathrm{C}
$$

at the center of the lobe. Hence

$d_{\beta+\gamma}=(3.0+9.1) C$ e.r. per day, $C$ being in $\mu c$ per gram of thyroid weight.

$D_{\beta+\gamma}=16.6 \mathrm{C}$ e.r. and $S_{\beta+\gamma}=0.1 / 12.1=0.0083 \mu \mathrm{c}$ per gram of thyroid weight. For a 25 gram thyroid this would mean $0.0083 \times 25=0.2 \mu \mathrm{C}$ of $\mathrm{I}^{130}$.

\section{Radioactive iodine- $\mathrm{I}^{131}$-(beta and gamma radi- ation)}

Following the same pattern used for $I^{120}$,

$$
\mathrm{d}_{\beta}=127 \times 0.08 \times \mathrm{C}=10.5 \mathrm{C}
$$

and $d_{\gamma}=0.66 \times 0.083 \times 17.6 \sim 1.0 \mathrm{C}$ at the center of the lobe; hence

$d_{\beta+\gamma}=11.5 \mathrm{C}$ e.r. per day if $\mathrm{C}$ is in $\mu \mathrm{C}$ per gram of thyroid weight.

$D_{\beta+\gamma}=139 \mathrm{C}$ e.r. (if there is no elimination).

As to the tolerance dose, $S_{\beta+\gamma}=0.1 / 11.5=0.0087 \mu \mathrm{c}$ per gram of thyroid; for the whole gland ( 25 grams) this would mean $0.22 \mu \mathrm{C}$ of $\mathrm{I}^{131}$.

These doses, which deliver $0.1 \mathrm{r}$ to the gland and less than one per thousand of this to the entire body, are obviously well below the accepted tolerance dose to the whole body. They correspond to oral or intravenous administration of 0.2 to $2 \mu \mathrm{c}$ per patient (to account for excretions of 10 to 90 per cent), and are sufficient for excretion studies as well as for assay of surgical biopsy material. They are, however, insufficient for radioautography with thin tissue sections, for extended studies of blood concentrations and for in vivo investigations of iodine retention by thyroid tissue by means of external detectors except, possibly, when scintillation counters are used. 
Studies on blood concentration and in vivo measurements would require doses of the order of five to 20 times those calculated (thyroid doses of 4 to 15 e.r. in about three weeks, if $I^{131}$ is used, taking into account elimination by the organ, and only .4 to 1.5 e.r. in two days for $\left.\mathrm{I}^{130}\right)$. Autoradiographic material can be obtained only with minimal concentrations of the order of several $\mu \mathrm{c}$ per gram of thyroid tissue (23). It seems therefore that in benign conditions, doses permitting excretion and tissue assays, blood concentration and in vivo measurements can be expected to produce no untoward effects, since the radiation is limited for a relatively short time to a very small part of the body which is not particularly radiosensitive. However, in the case of radioautographs, when radiation therapy or total thyroidectomy is not contemplated, every effort should be made to obtain them with the fastest film and low photographic density (23).

At this point it is well to consider that when tracer studies are to be carried out once or a few times on an individual, for diagnostic purposes, the physician may legitimately employ doses considerably in excess of those giving only the radiation permitted for continuous exposure. The diagnostic radiologist does not hesitate to give local exposures of several roentgens, and to repeat these at need. The justifiable dose in such cases must be determined by the clinician responsible for the patient.

The above examples illustrate the fact that no general statement can be made regarding the relative importance of the beta and gamma ray contributions to dosage. In the first place, the relative amount of energy emitted in the form of beta and gamma rays varies from one isotope to another. Also the geometrical factor $\mathrm{g}$, which is a function of both penetration of radiation and size of organ, is likely to vary tremendously with the problem, as in the cases of sodium and iodine.

\section{MISCELLANEOUS FORMULAE}

The weight of one millicurie of carrier free isotope can be readily calculated by noting that the weight of an atom of an element of atomic weight $A$ is $(A / N) \times 10^{3} \mathrm{mg}$ where $\mathrm{N}=6.02 \times 10^{23}$, Avogadro's number. Since $1 \mathrm{mc}$ of an isotope contains $1.44 \times \mathrm{T} \times 3.7 \times 10^{7} \times 8.64 \times 10^{4}$ atoms ( $\mathrm{T}$ in days) it follows that the weight of $1 \mathrm{mc}=1.44 \times 3.7$ $\times 10^{7} \times 8.64 \times 10^{4} \times 10^{3} \times \mathrm{A} \times \mathrm{T} / 6.02 \times 10^{23}=7.65$ $\times 10^{-9} \times \mathrm{T} \times \mathrm{A} \mathrm{mg}$. Values derived from this formula for the various isotopes are presented in Table I, column 10.

It seems of interest to close this paper with an illustration of the weights of radioelements necessary to produce marked radiation effects. This can be done by the following considerations. In order to deliver 1 e.r. to a tissue by means of a beta ray emitting isotope a concentration $\mathrm{C}$ is required such that

$$
\mathrm{C}=1 / 88 \overline{\mathrm{E}}_{\beta} \mathrm{T} \mu \mathrm{C} \text { per gram of tissue. }
$$

In terms of weight

$\mathrm{C}=7.65 \times 10^{-12} \times 10^{-3} \times \mathrm{A} \times \mathrm{T} / 88 \overline{\mathrm{E}}_{\beta} \mathrm{T}=8.7 \times 10^{-17}$ $A / \bar{E}_{\beta}$ gram per gram of tissue.

As an example, for $\mathrm{P}^{32}, \mathrm{~A}=32 ; \overline{\mathrm{E}}_{\beta}=0.7 \mathrm{Mev}$; hence for a lethal whole body dose of $1,000 \mathrm{r}$ the concentration required is $\mathrm{C}=8.7 \times 10^{-17} \times 32 \times 10^{3} / 0.7=3.98 \times 10^{-12}$ gram per gram of body weight (a total of $0.28 \mu \mathrm{g}$ for a $70 \mathrm{~kg}$ man). Since phosphorus constitutes only $1.14 \times 10^{-2}$ of the weight of the human body (24) only one atom in $2.85 \times 10^{9}$ atoms of phosphorus need be replaced on the average to obtain such an effect, on the assumption that no elimination takes place.

\section{SUMMARY}

When radioactive isotopes are employed either as tracers or in therapy, it is important to be able to determine the radiation dosage. This cannot, in general, be measured, but when the half life, radiation energy, and biological uptake and excretion are known, it can be calculated.

Since the basic information regarding radiation disintegration schemes and energies is scattered through many journals, it has been considered desirable to collect pertinent data. Two extensive tables are presented, for beta and gamma rays respectively, giving half life, radiation average energy, fraction disintegrating per day, and specific dosage data, including the safe tracer concentration, for some 33 isotope elements.

\section{BIBLIOGRAPHY}

1. Marinelli, L. D., Quimby, E. H., and Hine, G. J., Dosage determination with radioactive isotopes. Part II. Am. J. Roentgenol., 1948, 59, 260.

2. Evans, R. D., Tissue dosage in radio-isotope therapy. Am. J. Roentgenol., 1947, 58, 754.

3. Marinelli, L. D., and Kenney, J. M., The absorption of radiophosphorus in irradiated and non-irradiated mice. Radiology, 1941, 37, 691.

4. Erf, L. A., Clinical studies with the aid of radiophosphorus. II. The retention of radiophosphorus by tissue of patients dead of leukemia. Am. J. M. Sc., 1942, $203,529$.

5. Erf, L. A., Retention of radiophosphorus in whole and aliquot portions of tissue of patient dead of leu- 
kemia. Proc. Soc. Exper. Biol. \& Med., 1941, 47, 287.

6. Forssberg, A., A study of the distribution of radioactive phosphorus in three cases of cancer. Acta radiol., 1946, $27,88$.

7. Kenney, J. M., Radioactive phosphorus as a therapeutic agent in malignant neoplastic disease. Cancer Research, 1942, 2, 130.

8. Reinhard, E. H., Moore, C. V., Bierbaum, O. S., and Moore, S., Radioactive phosphorus as a therapeutic agent. A review of the literature and analysis of the results of treatment of 155 patients with various blood dyscrasias, lymphomas, and other malignant neoplastic diseases. J. Lab. \& Clin. Med., 1946, 31, 107.

9. Warren, S., The distribution of doses of radioactive phosphorus in leukemic patients. Cancer Research, $1943,3,334$.

10. Woodard, H. Q., and Kenney, J. M., The relation of phosphatase activity in bone tumors to the deposition of radioactive phosphorus. Am. J. Roentgenol., 1942, 47, 227.

11. Marinelli, L. D., Dosage determinations with radioactive isotopes. Am. J. Roentgenol., 1942, 47, 210.

12. Low-Beer, B. V. A., and Treadwell, A. de G., Clinical studies with the aid of radio-phosphorus. V. Early effect of small amounts of radio-phosphorus on blood cell levels, uptake, and excretion. J. Lab. \& Clin. Med., 1942, 27, 1294.

13. Jones, H. B., Wrobell, C. J., and Lyons, W. R., Method of distributing beta-radiation to reticuloendothelial system and adjacent tissues. J. Clin. Invest., 1944, 23, 783.

14. Lisco, H., The average man. Private communication.

15. Pecher, C., Biologic investigations with radioactive calcium and strontium; preliminary report on use of radioactive strontium in treatment of metastatic bone cancer. Univ. of Calif. Publ. in Pharmacol., 1942, 2, 117.

16. Treadwell, A. de G., Low-Beer, B. V. A., Friedell, H. L., and Lawrence, J. H., Metabolic studies on neoplasm of bone with aid of radioactive strontium. Am. J. M. Sc., 1942, 204, 521.

17. Greenberg, D. M., Campbell, W. W., and Murayama, M., 1. Studies in mineral metabolism with aid of artificial radioactive isotopes; absorption, excretion, and distribution of labeled sodium in rats maintained on normal and low sodium diets. J. Biol. Chem., 1940, 136, 35.

18. Hahn, L., Hevesy, G., and Rebbe, O., Do potassium ions inside the muscle cells and blood corpuscles exchange with those present in plasma? Biochem. J., 1939, 33, 1549 . Table VI.

19. Burch, G., Threefoot, S., and Reaser, P., Aspects of the biologic decay periods of sodium in normal and diseased man. Science, 1948, 107, 91.
20. Perlman, I., Chaikoff, I. L., and Morton, M. E., Radioactive iodine as indicator of metabolism of iodine; turnover of iodine in tissues of normal animal, with particular reference to thyroid. J. Biol. Chem., 1941, 139, 433.

21. Marinelli, L. D., and Hill, R. F., Radioiodine. Studies on dosage in cancer therapy. Brookhaven Conf. Rep., BNL-C- 5, July 1948, 98.

22. Marinelli, L. D., Trunnel, J. B., Hill, R. F., and Foote, F. W., Factors involved in the experimental therapy of metastatic thyroid cancer with I ${ }^{131}$. Radiology, 1948, 51, 553.

23. Marinelli, L. D., and Hill, R. F., Radioautography. Amer. J. Roentgenol., 1948, 59, 396.

24. Bodansky, M., Introduction to Physiological Chemistry. John Wiley \& Sons, New York, 1934, Ed. 3, p. 4.

References for those isotopes which are not included or supplement those in the paper of Marinelli, Brinckerhoff and Hine, Average energy of beta-rays emitted by radioactive isotopes, from Rev. Mod. Phys., 1947, 19, 25, are:

C14 Levy, W. P., Physical Rev., 1947, 72, 248.

$K^{42}$ Siegbahn, K., Archiv. foer Mat. Astr. o. Fysik, 1947, 34B, No. 4.

$\mathrm{Ca}^{45}$ Manhattan Project Announcement, Science, 1946, 103, 697.

Sc ${ }^{46}$ Peacock, C., and Wilkinson, R. G., Physical Rev., 1947, 72, 251.

$\mathrm{Mn}^{54}$ Deutsch, M., and Elliott, L. G., Physical Rev., 1944, 65, 211.

Fe $^{55}$ Bradt, H., Gugelot, P. C., Huber, O., Medicus, H., Preiswerk, P., Scherrer, P., and Steffen, R., Helv. phys. Acta, 1946, 19, 222.

Co ${ }^{60}$ Miller, L. C., and Curtiss, L. F., J. Research Nat. Bur. Standards, 1947, 38, 359.

Zn Ev Evans, R. D., Nucleonics, 1947, I, No. 2, p. 39.

As $^{76}$ Siegbahn, K., Archiv. foer. Mat. Astr. o. Fysik, 1947, 34A, No. 7.

Sr89 Rall, W., and Wilkinson, R. G., Physical Rev., 1947, 71, 321.

Sr ${ }^{90}$ Manhattan Project Announcement, Science, 1946, 103, 697.

Y ${ }^{86}$ Gamertsfelder, G. R., Physical Rev., 1944, 66, 288.

YoO Plutonium Project, Rev. Mod. Phys., 1946, 18, 513.

In ${ }^{111}$ Tendam, D. J., and Bradt, H. L., Physical Rev., 1947, 72, 1118.

Sb ${ }^{124}$ Meyerhof, W. E., and Scharff-Goldhaber, G., Physical Rev., 1947, 72, 273.

Au Siegbahn, K., Proc. Roy. Soc., 1947, 189, 527.

I31 Metzger, F., and Deutsch, M., Physical Rev., 1948, 74, 1640.

Sas Albert, R. D., and Wu, C. S., Physical Rev., 1948, 74, 847. 